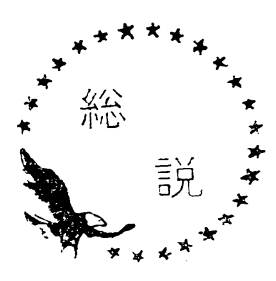

イモドコ・ターミナル (Imodco Terminal) の名称 は難解と考えられるのでまずその説明を記したい。

この考案の特許権を保有していた瑞典の会社名が, International Marine and Oil Development Corp. でこの頭文字を緅り合せ Imodco（イモドコ）とむつ かしい商品名ができた。この設備は一点係留ブイで係 留の目的に使用されるが, 一般ブイと機能的, 構造的 に大いに異なつていることを特に区別するために Terminal (ターミナル) と名称づけたのである。

このターミナルは米国人 Leory Martin Sylverst 氏 の考案で, 現在特許権の保有は米国の Imodco International 社で, 提携会社はつぎの 4 社である。

1. Imodco Italiana

2. Imodco London

3. Imodco Japan

4. Imodco U.S. A.

イモドコ・ターミナルを据付て操業中をたほ据付中 の場所, 寸法, 能力, 水深, および海底パイプ延長法 下表のとおりである。

日本においては同種の Shell 社型式ブイを昭和四日 市石油K.Kが据付操業中である。

原油輸送化使用するわが国のタンカーは大型化に拍 車をかけ輸送費の违減をはかつている。大型化で船舶 の造船費法重量 $\mathrm{t}$ 当り大幅に安価となるのみならず輸

Customer place dia. Tonnage

\begin{tabular}{|c|c|c|c|c|c|c|c|c|}
\hline 1 & Sweden & $\begin{array}{l}\text { Dalarco } \\
\text { (Sweden) }\end{array}$ & $5 \mathrm{~m}$ & $3,500 \mathrm{D} / \mathrm{W}$ & Diesel oil & - & - & $\begin{array}{l}\text { * は世界 } \\
\text { 最大の数 }\end{array}$ \\
\hline 2 & Saron Ref. & $\begin{array}{l}\text { Raveuna. } \\
\text { (Italy) }\end{array}$ & $12.5 \mathrm{~m}$ & $80,000 \mathrm{D} / \mathrm{W}$ & crude oil & - & - & $\begin{array}{l}\text { 但でのブイ } \\
\text { は寸法, }\end{array}$ \\
\hline 3 & Purfina Ref. & $\begin{array}{l}\text { Fumicino } \\
\text { (Italy) }\end{array}$ & $"$ & " & " & 径 $20^{\prime \prime}-4,500 \mathrm{~m}$ & $14 \mathrm{~m}$ & $\begin{array}{l}\text { 最大海底 } \\
\text { パイプの }\end{array}$ \\
\hline 4 & unknown & Alade S.A. & $5 \mathrm{~m}$ & $3,500 \mathrm{D} / \mathrm{W}$ & L. P. G. & - & - & $\begin{array}{l}\text { 延長最小, } \\
\text { 水深は最 }\end{array}$ \\
\hline 5 & " & Milazze & $"$ & " & " & - & " & 大である。 \\
\hline 6 & 九州石油 K. K. & 大分(日本) & $* 15 \mathrm{~m}$ & $100,000 \mathrm{D} / \mathrm{W}$ & crude oil & *径 $24^{\prime \prime}-900 \mathrm{~m}$ & $* 50 \mathrm{~m}$ & \\
\hline 7 & Korea Oil Co. & $\begin{array}{l}\text { Ulsan } \\
\text { (Korea) }\end{array}$ & $12.5 \mathrm{~m}$ & $80,000 \mathrm{D} / \mathrm{W}$ & " & 径 $20^{\prime \prime}-2,200 \mathrm{~m}$ & $15 \mathrm{~m}$ & \\
\hline 8 & 丸善石油 K. K. & 千葉(日本) & $15 \mathrm{~m}$ & $100,000 \mathrm{D} / \mathrm{W}$ & $"$ & *径 $30^{\prime \prime}-5,600 \mathrm{~m}$ & $17 \mathrm{~m}$ & \\
\hline
\end{tabular}

送費も 30,000D/W の場合より $130,000 \mathrm{D} / \mathrm{W}$ の場合 は 50\% 内外安価で中近東から原油を輸送することが できるといわれている。大型化の進展は未就航タンカ 一において平均 $80,000 \mathrm{D} / \mathrm{W} \sim 100,000 \mathrm{D} / \mathrm{W}$ で最大は $150,000 \mathrm{D} / \mathrm{W}$ あるいはそれ以上の大型の造船計画があ るといわれている。就航中の平均タンカーの 2 倍以上 の大型化はここ二三年で実現化されるのである。かか る大型化に対処して船具や受入設備はその充足進展は おくれ勝ちであるのが現状である。

原油受入設備に関し石油業各社は港の自然条件, 港 湾の周辺および泊地構成を初为, 港の装備状況などを 総括的に検討し最も建設費が安く作業費も経済的な設 備の選定に苦慮している。

九州石油はかかる条件を検討して, 世界最大のイモ ドコ・ターミナルを据付けることに決めたのである。 ターミナルは昭和 38 年11月末に現地据付終了, 12月 13 日德洋丸 $(50,300 \mathrm{D} / \mathrm{W})$ で実験をし, 各種作業上の資 料, 技術上の資料を収得し, 39 年 3 月 4 日雄洋丸入港 を初荷として12月31日までに23隻におよぶ役荷を無事 すました。23隻のうち8隻は外船で，15隻は邦船であ った。その荷揚量は約 149 万 $\mathrm{k} l$ で, 延送油時間は約 800 時間, 1 時間当り約 $2,000 \mathrm{k} l$ の荷揚げである。作

\section{III. 九州石油大分製油所の \\ イモドコ・ターミナル \\ 一昭和 39 年 10 月 15 日受理一}

九州石油株式会社 島 崎 和 彦 
業未熟, 船のポンプの故障などの原因で送油能力毎時 $3,000 \mathrm{k} l$ の約 $70 \%$ の平均送油能力の結果を示してい るが最大送油量 $3,000 \mathrm{k} l$ 以上であつた。

船舶の入港時は現在まで大体海上は平静であつた $20 \mathrm{~m} / \mathrm{s} \sim 15 \mathrm{~m} / \mathrm{s}$, 風速の突風や, 大雨の時もあつた が，荷役にはなんら事故なく遂行できた。最近第 14 号, 20 号台風が通過した時ブイは何らの事故なく安定 であつた。

九石が採用したターミナルの能力, 寸法および附带 船舶, ロープ船, ホース船の能力, 寸法はつぎのとお りである。

1）ターミナル（日立造船建造）

係留能力 $100,000 \mathrm{D} / \mathrm{W}$ タンカー 荷揚能力 毎時 $3,000 \mathrm{k} l$

直径, $15 \mathrm{~m}$ 重量, $181 \mathrm{t}$, (鋼板製二重底)

計算浮力 $755 \mathrm{t}$, 余裕浮力 $574 \mathrm{t}$

主な艤装品，a）コンプレッサーおよび発電機駆 動用 $32 \mathrm{Ps}$, ディーゼルエンジン 1 台

b) コンプレッサー, エアレシーバ - $\left(3 \mathrm{~m}^{3} \times 27 \mathrm{~kg} / \mathrm{cm}^{2}\right)$

c) 発電機

d） その他

固定用具 a) チェイン $88 \mathrm{~m} / \mathrm{m}(27.5 \mathrm{~m} \times 12$ 連 $\times 4$ 条)

$84 \mathrm{~mm}(27.5 \mathrm{~m} \times 3$ 連 $\times 4$ 条)

b) コンクリート クランプ $10 \mathrm{t}+4$ 個

c) アンカー $10 \mathrm{t} \times 2 \times 48$ 個

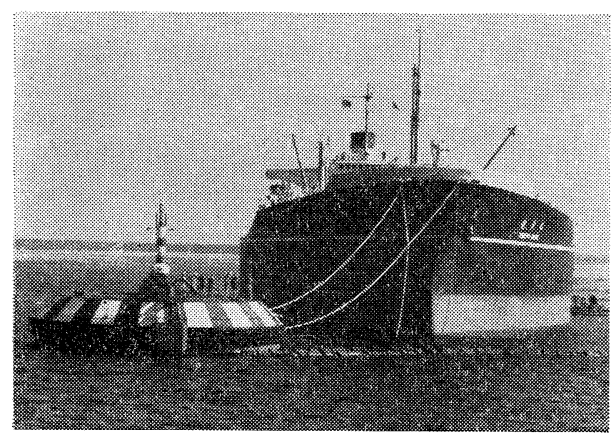

ロープ取が終了し，フロチングースが 本船にホース船で近寄つている。

輪型フロート附フロチングホース $(230$

$\mathrm{m}$ 長) 二条が平行して浮んでいる，

第 1 図イモドコ・ターミナル

(九石一号ターミナル) d） ホース，1ーターミナル海底パ イプ間の連絡ホース $12^{\prime \prime} \phi \times 10$ $\mathrm{m} \times 6$ 本 $\times 3$ 条 2 -フコチング ホース (エアホース共) $12^{\prime \prime} \phi \times$ $10 \mathrm{~m} \times 23$ 本 $\times 2$ 条

e） 海底鋼管パイプ $24^{\prime \prime} \phi \times 900 \mathrm{~m}$

2）ロープ船とホース船（各 1 隻, 新造)

ロープ船は, 本船をブイに係留する時, 口ープを本 船とターミナルの間を持運びするために使用し, ホー ス船はフロチングホースを本船が係留作業中, 本船よ り遠くはずし安全水域に維持し, 係留終了とともにつ ロチングホースを本船に近寄せ, 本船上に引揚げ作業 をするために使用する小型船舶である。しかし両船は 互換して使用することがある。

その他本船のマニホルドから船側までの送油短管 と, 支柱などを準備し, 本船が入港すれば軍び込み取 付け作業をするのである。

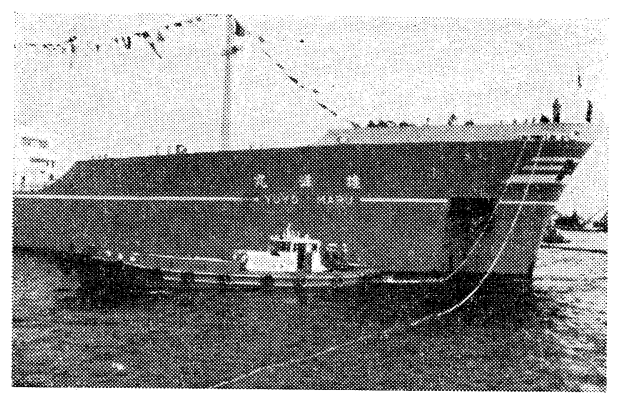

ナイロンホーサーを本船からターミナル へ持運んでいる。

䧸洋丸は $48,000 \mathrm{D} / \mathrm{W}$ で係留に使用した ロープは， $70 \mathrm{~m} / \mathrm{m}$ クレモナホーサー, $30 \mathrm{~m} / \mathrm{m}$ ワイヤロープ, $80 \mathrm{~m} / \mathrm{m}$ ナイロン ホーサーの 3 本をバイトに取つた。

第 2 図ロープ船（つるみ号）

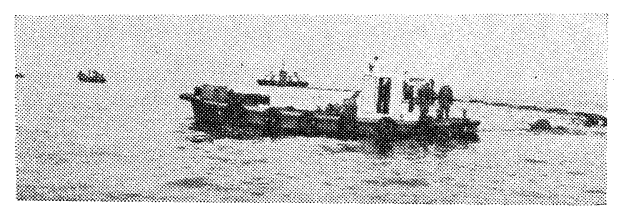

フロチングホースを安全海域に維持し て, 本船のターミナルに近接するのを待 つている。

ホースは 2 条で, 1 条の長さは $230 \mathrm{~m}$, 径は 12 in で, ホース内にエーヤホース が取付けられている。

第3図 ホース船（中心号） 


\begin{tabular}{|c|c|c|}
\hline 角 & 平水区域 & $\begin{array}{c}\text { 木 }- \text { 船 } \\
\text { 平水区域 }\end{array}$ \\
\hline 寸，法 & 長 $12 \mathrm{~m} \times$ 巾 $3.2 \mathrm{~m} \times$ 深 $1.5 \mathrm{~m}$ & 長 $17.3 \mathrm{~m} \times$ 巾 $4.0 \mathrm{~m} \times$ 媣 $1.73 \mathrm{~m}$ \\
\hline 総トン数 & $13 \mathrm{t}$ & $29.27 \mathrm{t}$ \\
\hline 機 関 & $\begin{array}{l}\text { 単動ディーゼル } \\
4 \text { cycle } \times 60 \mathrm{P}\end{array}$ & $\begin{array}{l}\text { 単動ディーゼル } \\
4 \text { cycle } \times 90 \mathrm{P}\end{array}$ \\
\hline 速度（最大） & 8 ノット & 11ノット \\
\hline 操＼cjkstart舵 & 遠方 操 作 & 遠方操 作 \\
\hline 荷役設備 & ナ シ & $5 \mathrm{t}$ ウインチ \\
\hline 型 & 大 発 型 & 大 発 型 \\
\hline
\end{tabular}

\section{I . ターミナルの構造と機能}

ターミナルは周囲にヘンダーをつけた円形構造で, ターミナル本体は回転しないで中央の円筒型のスイー ベルガ，ムアリングアームに掛けられたロープに張力 がかかるとムアリングアームとレボルビングアームと 一体となつて船舶と同一動きをして $360^{\circ}$ 回転するこ とができる機構である。ムアリングアームの端にロー プを取付けるシーブが 3 段あり，ホーサー直径が 80 粍 程度のものをバイトに取付けられる。またレボルビン グアームの端には本船とターミナルのスイベルとをつ なぐゴム製のフロチングホースが 2 条取付けられてい るが，このホースは平常は海底に沈んで浮上の時には ターミナルから圧縮空気がホース内部の空気ホースを 経て送風されホース内の海水を押出し先端から浮上す る。海底パイプとターミナルとの間にはゴム製のホー ス 3 条で連結されている。

本体は海底に 4 個所で固定されているが，水平移動 を制限して係留距離を小さくするように考案されてあ る。

以上のような諸機能を発揮させるためにターミナル の内部には自家発電装置, 空気圧接機㧍よび空気槽, 従業員休䕀室があり, また照明, 警報などの電源装置 として蓄電装置を完備している。タンカーへの給水, 給油は陸上からターミナルを経て供給できるように考 案されてある。ターミナルの据付㧍よび構造は第 4 ， 5,6 図のと抢りで, タ一ミナルの寸法, 浮力, 係船 能力はつぎに示すように規格化されている。

船舶は風の方向に向き風圧による最小の Pull Load の位置を保持するように移動するのである。チーエン の設計ロープの決定は Pull Load が最大な時の数值 を使用して安全率を高めてある。

Pull Load の算出式は種々あるが，つぎの公式を使 用している。

$$
R w=V^{2} k\left(A \cos ^{2} \theta+B \sin ^{2} \theta\right) \cdots(1) \text { (Wind Load) }
$$

$P=R w \cos \theta$ (2) (Pull Load)

$\theta=$ angle bet. wind and ships centre line $V=$ wind vel. $\mathrm{m} / \mathrm{s} . \quad k=$ coef, varying with $\theta$ $A=$ projected front area of ship $\mathrm{m}^{2}$

$B=$ " side

上の公式で Pull Load の最大は $\theta=30^{\circ} \sim 40^{\circ}$ であ る。

つぎに $\theta=90^{\circ}$ となつた場合，すなわちコンベンシ

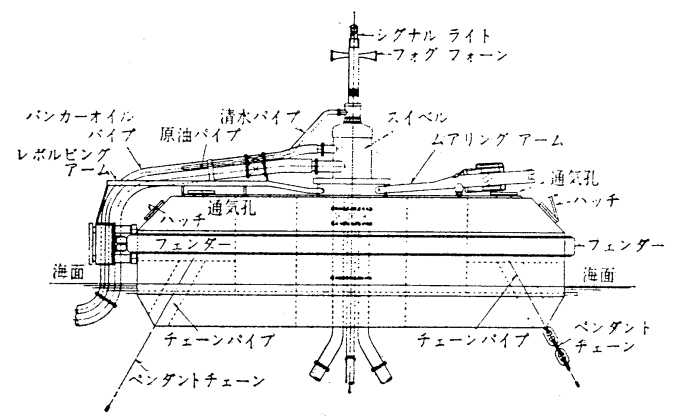

第 4 図 右一ムアリングアーム 左一レボルビングアーム

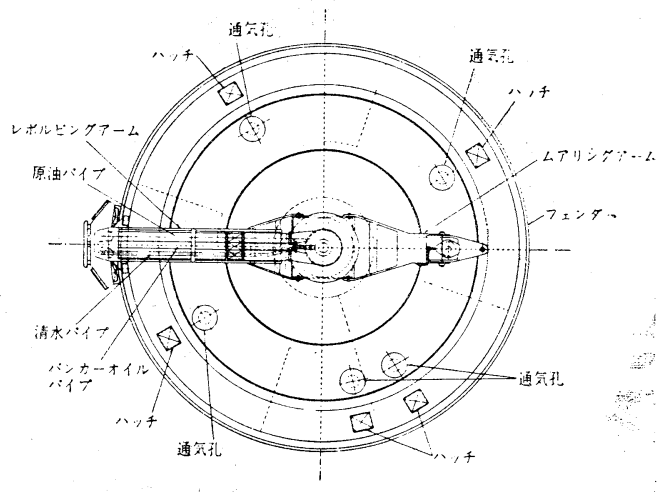

第5図ブイの平面 


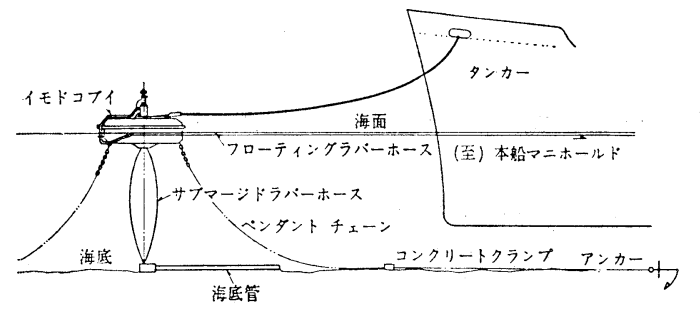

注）海底パイプは電気防食してある

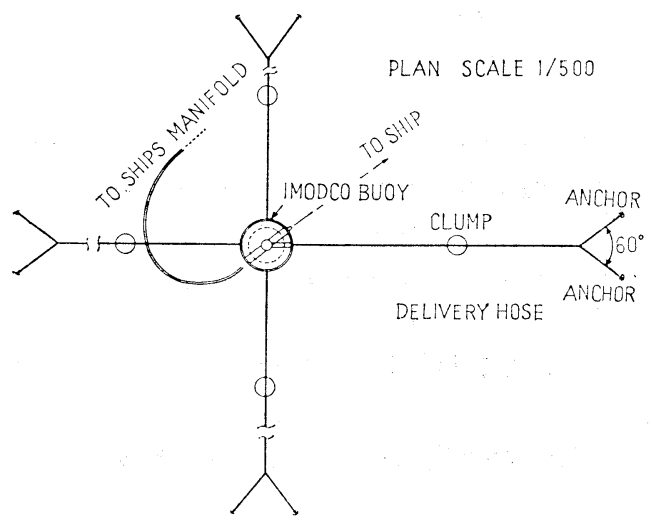

ロープの長さ $200 \mathrm{~m}$ でバイトに取る。タ

ーミナルと本船とは約 $50 \mathrm{~m}$ の距離を保

つようにロープ取りをする。

第 6 図ブイの 据 付

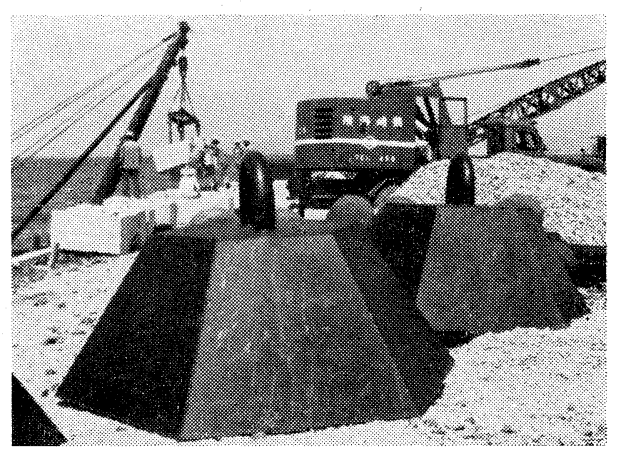

第7図 $10 \mathrm{t}$ のコンクリートブロック

$\begin{array}{cc}\begin{array}{c}\text { Dia. } \\ \text { of Terminal }\end{array} & \begin{array}{c}\text { Tanker to be } \\ \text { moored }\end{array} \\ 5 \mathrm{~m} & 1,500 \sim 3,000 \mathrm{D} / \mathrm{W} \\ 7.5 \mathrm{~m} & 7,000 \sim 10,000 " \\ 10 \mathrm{~m} & 21,000 \sim 30,000 " \\ 12.5 \mathrm{~m} & 62,000 \sim 74,000 " \\ 15.0 \mathrm{~m} & 100,000 \sim 150,000 " \\ 17.5 \mathrm{~m} & 190,000 \sim 270,000 " \\ 20.0 \mathrm{~m} & 305,000 \sim 480,000 "\end{array}$

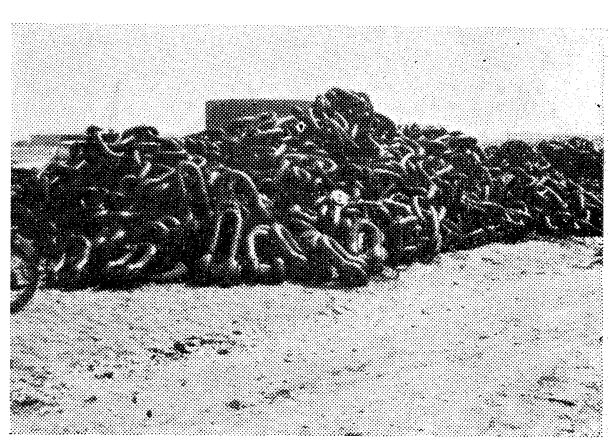

第 8 図 88粍のチェーン

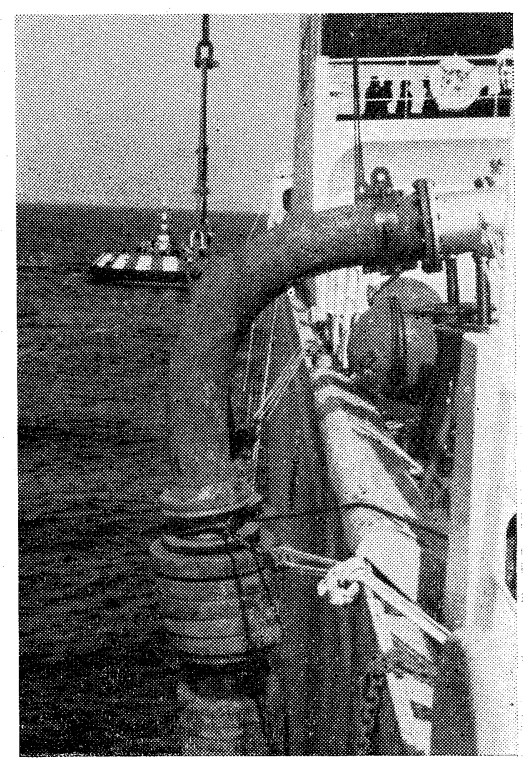

第 9 図 本船にフローチングホースが 連絡され送油中

フローチングホースの端にはエルボーが あり、本船のマニホールドからの連絡管 と,フランジジョイントされる。ホース には円筒型のフロートが自由にさし込ま れている。

Depth. Hull wt. Buoyancy

$1.85 \mathrm{~m} \quad 0.5 \mathrm{t} \quad 26 \mathrm{t}$

2.30 " $\quad 15.0$ " 85 "

$3.00 " 35.0 " 200 "$

$3.75 " \quad 80.0$ " $\quad 447 "$

$4.40 " 130.0$ " $750 "$

4.70 " 180.0 " $1,140 "$

$5.20 " 240.0 "$ 1. 760 " 
ヨナルブイで風圧を真横から受けた場合で係留索にか かる風圧はイモドコ・ターミナルにかかる圧力の 2 倍 弱の值で係留索に無理な荷がかかるように考えられ る。

イモドコ・ターミナルの特に波浪中の安全性につい てはターミナルのメタセンターの高さが $10 \mathrm{~m}$ 以上で 非常に高いためローリング周期は小さい。したがつて 波浪中においては自由に上下動するし，自由に動摇す るので相当量の水頭でターミナル上部に襲いかかるこ とはなく安全である。

作業時間は海上条件で異なるが大体つぎのごとき所 要時間である。

$\begin{array}{ll}\text { フロチングホース浮上時間 } & \text { 15分 } \\ \text { 倸留綱取り作業 } & 40 \text { 分 }\end{array}$

フロチングホースをマニホルドに連絡する作業 1 時 間

以上で送油開始となるが送油開始までの所要時間は 約 2 時間 2 時間 30 分で終了する。

送油終了すると水押してパイプ内の油を陸上の水切 タンクに受入れる。所要時間 30 分

フロチングホース取外し 40分

ホーサー取外し 30分

タンカー離脱 15分

送油終了からタンカー離脱までの所要時間 1 時間 30 分〜 2 時間程度である。

作業要員は作業主任が本船に常時駐在し, 会社本部 と無電で連絡をとりつつ指揮をとる。

ロープ船, 5 名, ホース船 5 名, 本船上 2 名で相互 に作業援助をしチーム 12 名で送油中は点検のため 3 5 名をターミナルおよび点検船に常駐している。

\section{II. 別府湾の自然条件}

九州石油は第 9,10 図のごとく別府湾の南側大野川 の河口, 36万坪の埋立地に原油処理 40,000bbl の規模 で設けられ，旧鶴崎市の工業立地区域で昨年新産業都 市大分市に合併された。九州石油の対岸との距離は図 示されたごとく，また国東～佐賀関間の山岳は $\mathrm{N}-\mathrm{W}$, $\mathrm{S}-\mathrm{W}$ 方向の風をさえぎり, 波浪に対しては有効な役 割をしている。ただ E-N 方向は開放的で高波を招来 せしめる条件を有している。一般に暴風時の春夏期は $\mathrm{E}-\mathrm{N}$ 方向の風が多く, 秋, 冬期は $\mathrm{N}-\mathrm{W}$ 方向の季節 風が多いのが同地区の風向条件である。水深は海岸よ り急に深くなり $20 \mathrm{~m}$ の水深は第 12,13 図のごとく $200 \mathrm{~m}$ 沖合に求められる。イモドコは船の長さの約 3 倍以上を岸壁より沖合に保つことが係船安全条件とい われ沖合 $900 \mathrm{~m}$ の個所腚めたのである。この個所の

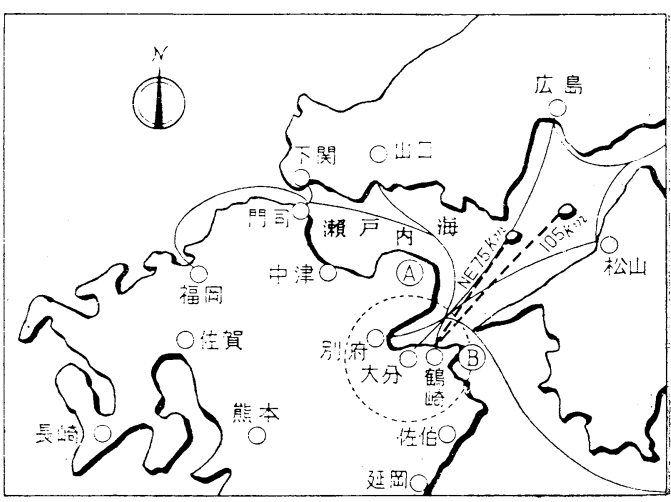

第10図大分鶴崎の位置

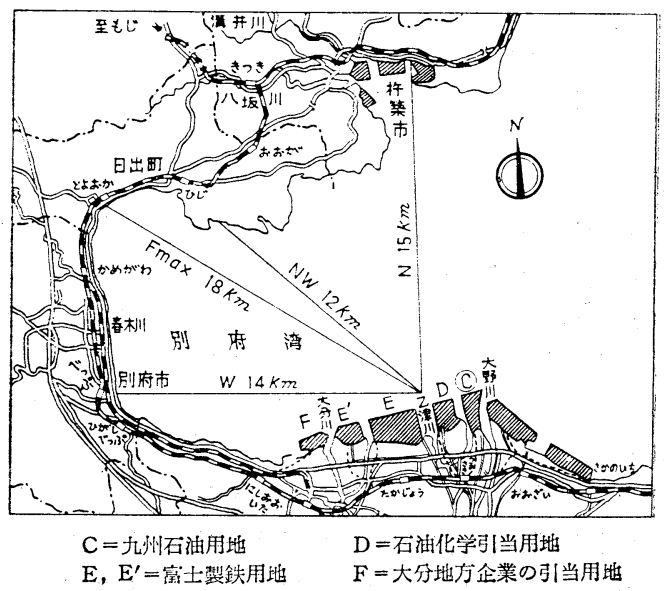

第11図 別府湾と九石の配置関係

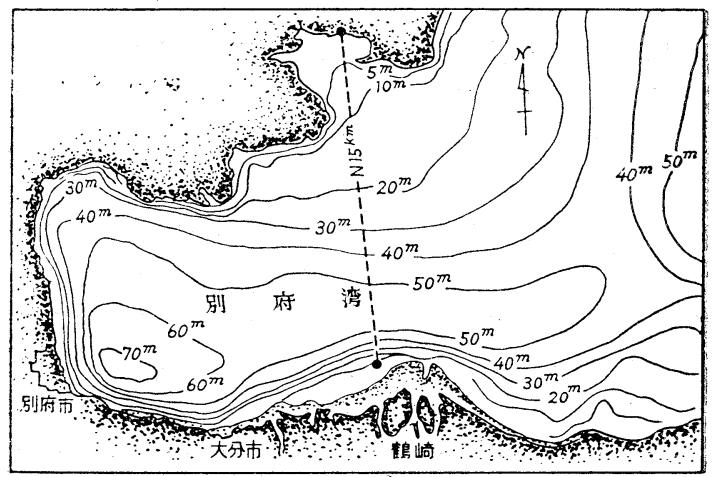

第12図 別 府湾の水深 

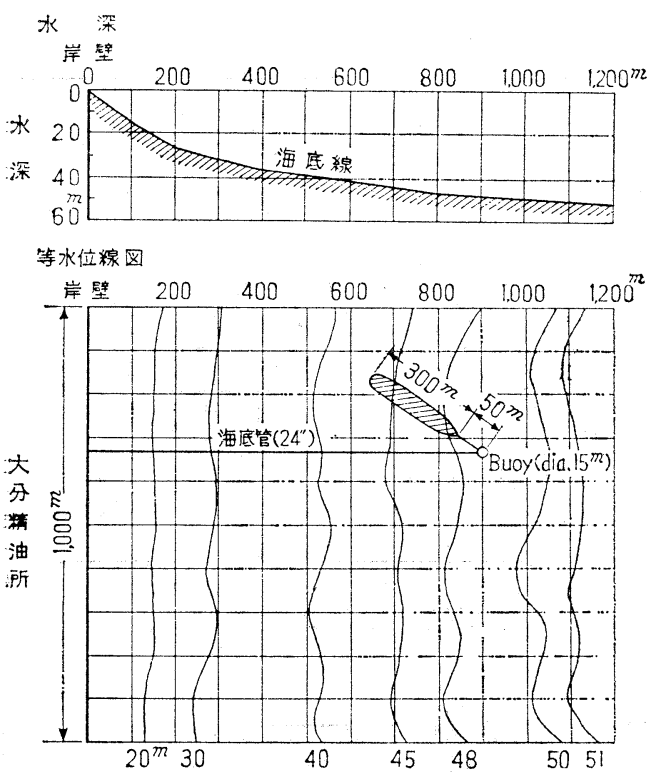

第13図 工場岸壁とブイの設置個所との関係

水深は $50 \mathrm{~m}$ で深すぎるのである。

ロープ船，ホース船および通船などの小型船舶の航 行およびロープ取の安全可能作業は, 最大波高を 1.2 $\mathrm{m}$ 風速 $12 \mathrm{~m}$ として（米国海岸工学会の資料から一応 制限した）別府湾の自然条件を考えると，各種の観測 資料あるいは試算などから風速 $6 \mathrm{~m} / \mathrm{s}$ 内外の風が冬季 $10 \sim 20 \%$ を占め, $10 \mathrm{~m} / \mathrm{s}$ の風の発生度は僅小であ る。有義波高 $1.0 \mathrm{~m}$ 以上の発生頻度を各種資料から検 討すれば風向, その他要因で異なるが昭和 38 年 2 月 13 日〜 月23日の期間で 164 回の波浪測定結果では29回 であつた。 $\mathrm{N}-\mathrm{W}$ 範囲の波高 $1.0 \sim 1.5 \mathrm{~m}$ の発生は 9 回, E-N 範囲は20回であつて。 $\mathrm{N}-\mathrm{W}$ 範囲は $31 \%$ の 発生比率である，季節風において各種試算の結果によ れば, $1.0 \mathrm{~m}$ 以上の波高を発生せしめる風速は大体 $11.0 \mathrm{~m} / \mathrm{s}$ 以上である。以上の自然条件資料から, 別府 湾においてはまず安全作業ができ得ると判断したので ある。

また月最高潮位出現頻度を資料より調べると一番多 いのは $2.0 \sim 2.3 \mathrm{~m}$ である。既往最高は昭和 18 年 9 月 20日の $3.483 \mathrm{~m}$ であつた。ターミナルの下部連絡ホー スおよびチェンの設計に際しては，以上の資料を取入 れて安全をはかつている。ただ潮流の状況はいまだ測 定し難く, 深海であること, 大野川の川口に近い位置 にある点から混乱しているように考えられる。静波時 の船舶碇泊位置の安定性がない。しかし作業には支障 はないのである。

\section{III. 大分製油所の立地と港湾設備および 船舶受入設備}

大分製油所は第一号埋立地 36 万坪の内 30 万坪を使用 乙 、北は $1 \mathrm{~km}$ の前面岸壁, 東は大野川の岸壁, $1.5 \mathrm{~km}$ 西は鋼矢板で築造した船舶出入の接岸岸壁，南は陸つ づきで九州電力発電所用地に隣接している。三面が海 に接した扇形の地形である。

泊地は第二号埋立地との間にあり，その幅は $470 \mathrm{~m}$ で $400 \mathrm{~m}$ は水深 $13 \mathrm{~m}$ 一号地寄りの岸壁は $6 \mathrm{~m} \sim 4 \mathrm{~m}$ の 水染で, $3,000 \mathrm{t}$ 以下の船舶の倸留ができる。

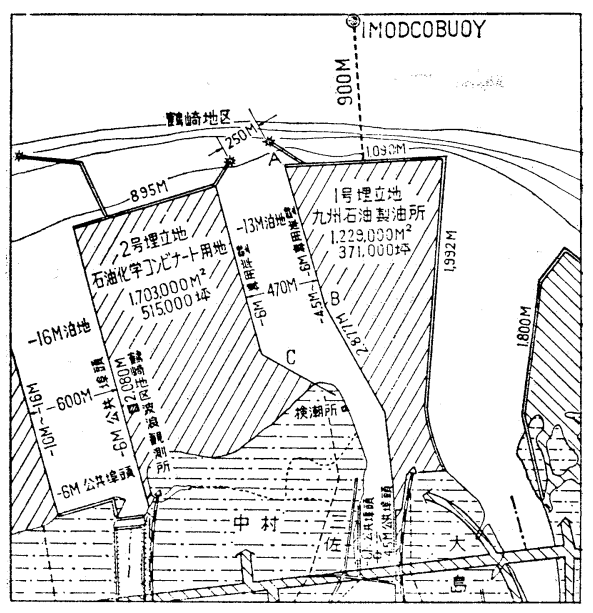

第14図九石の泊地

前面護岸高は標高 $5.5 \mathrm{~m}$ で消波のためテトラポット を根元に投置し, 大野川岸壁根元には蓄砂のため各種 のブロックを投置して岸壁の保護をした。

泊地入口には第一, 二号埋立地の先端から防風堤を 突出し築造され有效泊地入口寸法は $200 \mathrm{~m}$ とした。第 一号埋立地よりの防風堤は N-E 方向の台風時の風波 を防ぎ，第二号地よりの防波堤は季節風 $\mathrm{N}-\mathrm{W}$ 方向の 波を防ぐのに有効である。

工場用地は L.W.L. から $3.5 \mathrm{~m}$ 高に盛土した。 泊地の船舶接岸可能の直線距離は約 $800 \mathrm{~m}$ で, 将来 工場拡充の際の出入小型船舶の接岸に, 充分でなく泊 地内の沖待船舶も増加するものと考えられる。また泊 地に $150,000 \mathrm{D} / \mathrm{W}$ 級以上の大型タンカーを受入る と, 少なくとも $350 \sim 400 \mathrm{~m}$ 岸壁を独占し, 出入には 泊地の幅員から考えて, 一時航行禁止するがごとき処 置をしなくてはならないので, 原油受入設備は泊地外 に決めざるを得ない泊地構成である。

大型タンカー接船用設備決定に関しては, 上記のご とき泊地構成, 前記した海の自然条件, 別府湾周囲の 
山岳分布構成などを考慮するほか，港湾装備の現状お よびその整備見通しなどを考えた。特に装備の内曳船 がなく，いま急速に公共性のある曳船の実現は至難で めることが検討されたので，曳船を要しない設備を考 えたのである。

現在邦船は水先および曳船は使用していないが，外 船の場合は不案内のため水先で誘導して, 曳船一隻を 一応手配しているが，ほとんど使用することなく帰航 さしている。上記のごとく曳船を使用する場合は，関 門地区，あるいは中国地区から回航され，その経費注 相当高価なものとなつている。

もしドルヒンおよびその他のタンカー受入設備で, 船舶の出入に $1,500 \mathrm{P}$ 程度の曳船を四隻使用すると考 えると，その経費はますます高価なものとなる。

つぎに受入設備を泊地外に設けるとすれば，沖合の 水深が急深で問題でないが，大型化による船舶の長さ が $300 \mathrm{~m}$ となると，係留技術や不虑の場合の船の安全 性から船長の三倍以上の距離を要請されるので, 九石 の場合沖合 $900 \mathrm{~m}$ となつた。以上の理由と経済性から 100,000D/W タンカー受入可能のイモドコ・ターミナ ルを選定したのである。つぎに一点係留方式の一般的 利点は下記のとおりである。

1）一点係留係船方式であるから，開放された海域 に設置できる。しかし，海の自然条件により係留

比 イモドコ・ターミナル

係留法1. 曳船は絶対条件ではない

2. 係船時間が短かい（錨を上げ接近初めて から約 1 時間) 係留索は 3 本である。

ブ

1. 一点係留であるから風下に自由に回るの で，風圧や潮流圧が最低になる位置に移 動する。

作 業 員 1 . 係留時の作業要員は12名内外で, 送油中 は点検のため 5 名位必要である。

建 設 費 1 . ブイの建設費は高価である，特にフロチ ングホース，チェーン，錯が高価であ る。

通 信 法 1 . 無線電話で通信可能
可能また不可能の場合があることは検討すべきで あるが，水深が遠浅であつても沖合数籸の地点に 設置し，大型船舶の係留を可能ならしめること は，工業立地上重大な影響がある。日本でも 6 料 沖に設置する計画がある。

2）不幸にして火災が起きても，船舶自体に極限す ることができる。

3） 入出港でないので港則法などによる入港制限, 潮待ち, 荷役設備使用制限を受けることがない。 また水先，曳船なども必ずしも必要でない。した がつて役荷時間が短縮され，滞船時間が少なくな る。

4）港湾管理面からは水路の補修は，全然なくその 維持経費は不要である。

5）本船への給水または給油を，パイプにより送る ことができるので，小型船舶が必要でない。

大型タンカー受入設備として, 泊地の岸壁に直接接 岸できるドルフインを設けることができない場合は， コンベンショナル，ブイまたはイモドコ・ターミナル が考えられるが，前述のような利点および自然条件な ど検討の上，イモドコ・ターミナルを選定したのであ るが，コンベンショナルブイと，イモドコ・ターミナ ルの設備および作業面から比較してみるとつぎのごと くなる。 
衝突予防法 ブイ内に自家発電により標識灯の点滅ができ な る。陸上より霧笛を鳴し得るようにでき予防 を講じてある。

作 業 船係留用ロープ船とホース船の小型船 2 隻は必 要である。

安 全 性 1 . ブイの径が大きいので係留作業は安全で ある。

2. ブイは 4 本のチエンで海底に固定されて いる。な招气のチエンの延長は水深の 6 倍位あり, 強度も強いので本船の索引に よる移動はブイの半径位である。

3. 本船との係留索は 3 本以上で, 且バイト にとることができる。

木 一 ス

1. 海底に沈められたホースは送気により， 浮上できマニホルドとの連絡が容易であ る。

荷 役 費曳船の雇用また回航費を考えることがないの で, 総体的には安価である。係留, 送油, 離 船などの合理性から滞船時間が少ない。

補 修 費 機械設備が多くホースも長いので補修費, 維 持費は高価である。

給水給油法

給水または給油の小型船舶を必要としない。
係留時にはブイの数が多いので小型多数必要 である。

1. ブイの径が小さいので傾くことが多く特 に荒天時は係留作業はむずかりい。

2. ブイ自体は 1 本のチェンで固定されてい るので，本船の索引により水深が深い程 移動量が大きく，ブイが水没する場合が ある。

3. 本船との係留索は 1 本でバイトに取るこ とができない。

1. 海底に沈められたホースは, 本船上のデ レッキで吊上げるので，その作業は困難 であるのみならずこの作業のためにホ 一スに破損を与える場合がある。沈下し ている状況をみるため点検が必要である。

曳船費用，ホース点検引揚げ費用，滞船時閒 などを考慮すれば，総体的には高価となると 思慮する。

機械設備はなく，ホースも短いので補修費は 安いと考えられる。

必要である゚

\section{結＼cjkstart論}

タンカー船の大型化はわが国石油需要の増大に起因 することは明らかであるが，この長足の需要の伸びを 満すために消費地精製の招来となり。わが国の業界で は海岸沿いの埋立地を選び工場の建設がすすんでい る。いかに安い原油を入手するかが企業を左右するも のである。

わが国は原油を中近東に求めているので，輸送距離 が最大化している関係上，採算的にも輸送単位の増大 が要求されるのである。この要求を満すために造船技 術の進展, 鋼材の改善, 主機製造の進歩などがあり, その目的が達成される大型タンカーの実現となつたの である。

しかるに大型化の船舶の受入設備や港湾の条件係留 用器の整備など，必ずしも充分でないのである。現在 100,000D/W 以上のタンカー船を岸壁に横ずけし得
る個所は，わずかである。沖合遠く通称「うまつなぎ」 の設備で目的を満している個所がある。また Imodco Terminal もその一例となるのである。

港湾の自然条件すなわち潮流, 水深, 風浪, 海面の 広さなどを研究することにより, 従来より Imodco Terminal を採用する可能性が九石の例をもつて進展 するのではないかと信ずるのである。

幸か不幸か，今日まで23回の入港に際し送油不可能 のこともなく，すでに 150 万 $\mathrm{k} l$ 以上の揚荷を完了し たのである。また 14 号ならびに風速 $42 \mathrm{~m}$ の 20 号台風 にも遭い，Terminal の安全性は立証されたのである。 今後海岸沿いの工場に限らず海岸に近い内陸の工場 にも港湾の自然条件が満足されるなら, Imodco Terminal の採用により原油および油製品の遠方輸送も可 躀となり，工業促進の一助となることと信じて止まな W。 


\title{
IMODCO Terminal in Ōita Refinery, Kyushu Oil Co., Ltd.
}

\author{
by Kazuhiko Shimazaki \\ (Kyushu Oil Co., Ltd.)
}

\begin{abstract}
SYNOPSIS : - The Imodco Terminal is a monomooring buoy, its name being derived from International Marine and Oil Development Corp. (Sweden), its original patentor of this invention.

In Japan owing to the necessity of reducing transportation cost of crude oil construction of large-sized tankers is being promoted. Oil men, taking into consideration the natural conditions of the harbour and its surroundings together with berth and dolphin facilities, are concentrating upon the selection of facilities which are most economical both in construction and in operation costs.

Kyushu Oil Company installed in the spring of 1963 the world's largest Imodco buoy in Beppu Bay, as it was concluded that such mooring facility had more advantages in that specific surroundings as compared with the conventional bouy. This terminal has snccessfully unloaded approximately $1,500,000 \mathrm{kl}$ of crude oil by the end of that year.

This paper describes the structure and the function of the Imodco Terminal, and natural conditions of Beppu Bay.
\end{abstract}

\section{石炭工業の化学化の諸問題}

石炭化学工業の発展と石炭釷業技術への化学産物の利用という二問題に絞り, とくに燃料研究所や科学ア カデミー・スコチンスキー鈗山研究所その他の研究を中心に, 現状および将来性について論説している。た とえばソ連炭に含まれている天然樹脂を抽出精製して高品質強化プラスチックの原料にするための，とくに グルジヤのトキブーリスキー炭に対する純残留生成岩抽出工程の研究, エストニヤ地方のけつ岩の有機物質 を利用する方法としての硝酸酸化による脂肪族のジカルボン飽和酸の生成の研究があげられる。選炭への化 学薬凨の利用拡大についても諭じている。

Уголь, 39, 6, (1964)

\section{無水フタール酸エ場}

英国の Grange Chemical 社は, Hull の新工場で，石油を原料とした無水フタール酸を製造，まず初年 度は 15,000 t の予定, 製造方法は California Chemical 社が開発したもので,オルトーキシレンをベース とした方法である。

今日まで石炭を原料としていたが，今回はじめて石油を原料する無水フタール酸を製造することになつた もので, 他にも Laporte Indastriles 社が計画中といわれる。な㧍その用途は, 塗料用アルキル樹脂や塩化 ビニルの主要可塑剤, その他ポリエステルの生産に用いられる。

Engineering, 198, 343 (1964) 